\title{
A multi-centric prospective study: Anxiety and associated factors among parents of children undergoing mild surgery in ENT
}

\author{
Çok merkezli prospektif çalışma: KBB'de orta derecede cerrahi geçiren çocukların \\ ebeveynlerinde kaygı ve ilişkili faktörler
}

Mehmet Akdağ ${ }^{1}$, Zeynep Yıldırım Baysal ${ }^{2}$, Abdullah Atlı $^{3}$, Baver Samancı ${ }^{4}$, İsmail Topçu ${ }^{1}$

\begin{abstract}
Objective: The aim of this study to evaluate the anxiety and expectancy among parents of children undergoing surgery in the multi-centric surgery units.

Methods: Following approval from the ethics committee, a questionnaire was given to the parents of 123 children who were undergoing surgery in the multi-centric surgery units. The parents were informed that their answers would not affect the care given to their children. The questionnaire was evaluated using the State-Trait Anxiety Inventory (STAI-I and STAI-II).
\end{abstract}

Results: The STAI results indicated that the parents' anxiety level increased before their children underwent surgery. In addition, there was a negative correlation between STAI-II scores and high levels of wealth $(p=$ 0.004 ). Also, those with steady employment and higher levels of education had lower anxiety levels and difference was significant $(p=0.001)$. The state anxiety levels were unaffected by family income and education, but the trait anxiety levels decreased with increasing income and education. Mothers were less anxious if their child had undergone surgery in the past, while this result was not significant statistically ( $p>0.05)$. Parents were most commonly concerned with possible complications from the surgery and/or anesthesia.

Conclusion: Results of our study indicate that parents of children undergoing surgery that have steady employment, to be informed, previously has been administered anesthesia or surgery, high level of wealth and education was observed less anxiety than others. J Clin Exp Invest 2014; 5 (2): 206-210

Key words: Anxiety, pediatric surgery, STAI
ÖZET

Amaç: Çalışmamızın amacı çok merkezli cerrahi ünitelerde opera olan çocukların ebeveynlerinin beklenti ve anksietelerini değerlendirmektir.

Yöntemler: Etik kurul kararı alındıktan sonra çok merkezli cerrahi ünitelerde opera olan 123 çocuğun ebeveynlerine soru içeren anket formu verildi.Ebeveynlere verecekleri cevapların çocuğun bakımını etkilemeyeceği bildirildi. Anketler STAI-I VE STAI-II ölçekleri kullanılarak yapıldı.

Bulgular: STAI sonuçları cerrahi geçiren ebeveynlerin anksiete altında olduklarını gösterdi. Ayrıca STAI -II skorları ile maddi zenginlik arasında negative ilişki bulundu( $p=$ 0.004). Yine düzenli iş sahibi olma, eğitim düzeyinin yüksek olması anksiyeteyi düşüren önemli farklılıklar olup bu fark istatistiki olarak önemli idi $(p=0.001)$. Ekonomi, eğitim düzeyi durum kaygı düzeylerini etkilemezken; sürekli kaygı düzeyi ekonomik durumun iyi olması, bilgilendirme ve eğitim ile azalır. Daha önceden çocukları cerrahi geçiren daha az anksiteli skorlarına sahip olmalarına rağmen bu sonuç istatistiki olarak önemli değildi $(p>0.05)$. Ebeveynler sıklıkla cerrahi veya anestezi ile ilgili muhtemel komplikasyonlardan endişeli idiler.

Sonuç: Bu çalışma bize çocuğu daha önce opere veya anestezi alanlar, bilgilendirmiş olma, iyi ekonomik düzey ve yüksek eğitim düzeyi diğer faktörlere göre anksiyeteyi azalttığını gösterdi.

Anahtar kelimeler: Anksiete, çocuk cerrahisi, Anksiete Durum ölçeği

${ }^{1}$ Dicle University, Faculty of Medicine, Department of Otolaryngology, Diyarbakir, Turkey

${ }^{2}$ Dicle University, Faculty of Medicine, Department of Anesthesia, Diyarbakir, Turkey

${ }^{3}$ Dicle University, Faculty of Medicine, Department of Psychiatry, Diyarbakir, Turkey

${ }^{4}$ Specialist of Otolaryngology, Department of Otolaryngology, Private ENT Surgery Centre Clinic, Diyarbakir, Turkey

Correspondence: Mehmet Akdağ,

Dicle University Medical School, Department of Otolaryngology Diyarbakir, Turkey Email: drmehmetakdag@hotmail.com Received: 20.03.2014, Accepted: 21.10.2014

Copyright (C) JCEI / Journal of Clinical and Experimental Investigations 2014, All rights reserved 


\section{INTRODUCTION}

Although there have been many advancements in surgical and other treatment techniques, surgical events remain a cause of stress and anxiety for patients and their families. Elective surgeries, such as tonsillectomy and adenoidectomy are quite common in children.

Anxiety is defined as a set of behavioral manifestations that can be measured by the State-Trait Anxiety Inventory (STAI). The STAI measures both state anxiety (anxiety regarding an event) and trait anxiety (anxiety as a personal characteristic). State anxiety is attributed to acute, situation-driven episodes of anxiety that do not persist beyond the situation that triggers them. It is a transitory, emotional condition that consists of feelings of tension, fears, nervousness, and worry, and of heightened autonomic system activity. State anxiety varies in intensity and fluctuates over time [1,2]. Trait anxiety is a lifelong pattern of anxiety, and is a personality feature. Persons with trait anxiety are generally tense, nervous, hypersensitive to stimuli, and are psychologically more reactive. High state anxiety scores indicate high levels of anxiety during the evaluation, while high levels of trait anxiety indicate an anxious personality [3].

The State-Trait Anxiety Inventory (STAI) is commonly used to measure trait and state anxiety. It can be used in clinical settings to diagnose anxiety and to distinguish it from depressive syndromes. It is used for diagnosis in clinical settings, in other medical settings, and in research. Higher scores are positively correlated with higher levels of anxiety.

Anxiety is the most commonly reported peri-operative emotional response, with a prevalence of up to $60 \%[4,5,6]$. Although elective surgeries are usually basic and pre-planned, the child may feel that the surgery is a threat to his/her physical unity and may even have a fear of dying during surgery. The situation is even more difficult for parents. Nevertheless, most of the studies evaluating children undergoing elective surgeries have focused on the assessment of anxiety, and not its prevention. Further, most of these studies have not evaluated the parents' symptoms lately, although parental anxiety is often addressed with the physician during the preparation for the surgery. Also parents' anxiety can be stressful for their children or doctor and anxiety of parents about their children's anesthesia or surgery may adversely affect the children's outcomes and compromise the quality of informed consent. Kain et al. [6] showed that parental anxiety is directly cor- related with children's preoperative anxiety. In addition there was little comparatively research has been conducted to understand the preparation and expectations of parents, pre-operatively, and how we experience making the decision to have a less anxiety recently.

For these reasons the aim of this prospective clinical study was to evaluate the levels and causes of anxiety that affected parents of children who underwent outpatient elective mild surgery in centre of ENT.

\section{METHODS}

This study was approved by the Ethical Committee (17.2.2012/35) and included 123 pediatric patients who were admitted to the Department of Otolaryngology surgery units at Dicle University Medical Hospital and at Academy Private ENT surgery clinic between February 2012 and November 2013. The anxiety levels of the patients' mothers and fathers (who provided informed consent) were measured by Spielberger's [3,7] State-Trait Anxiety Inventory questionnaire (STAI-I and STAI-II), which is a selfreport questionnaire that scores parental anxiety. The questionnaire includes two subscales with 20 items each, with each item rated on a 4-point scale. It is one of the most frequently used self-report instruments for evaluating parent anxiety. The STAI offers high reliability and satisfactory validity, and is the gold standard for measuring preoperative anxiety [8]. It is a well-researched clinical tool for evaluating the current state of anxiety (State-I) and the tendency towards anxiety (STAI-II). A cut-off point of 39-40 typically indicates clinically significant symptoms of a state of anxiety. The questionnaire was given to the parents by the charge nurse or by a researcher immediately before their child was taken to the operating room. Parents were permitted to answer the questions in a quiet place without any impact. All surgical cases undergoing surgery (ASA I and II) on the tonsils and adenoids under general anesthesia were selected for the present study.

Cases undergoing major surgery (e.g., laryngeal cancer) or other minor surgeries (e.g., abscess drainage) were excluded from the study. In addition, parents using psychiatric drugs were not accepted in study.

\section{Statistical Analysis}

Data analysis was performed using SPSS for Windows, version 15.0 (SPSS Inc., Chicago, IL). The frequency of the parents' age, level of wealth, and 
education was evaluated with a frequency analysis. An Independent $T$ test was used to analyze gender. A Pearson Correlation Test was used to find differences between STAI-I and STAI-II. An ANOVA test was used to make comparisons between and within the three groups. Two-tailed hypotheses were considered, and $p<0.05$ was accepted as significant.

\section{RESULTS}

The average age of the parents was $36.0 \pm 6.8$ years and their ages ranged from 23 to 57 years. There were $71(57.7 \%)$ female and $52(42.3 \%)$ male parents. There was no significant difference between age and the STAI-I and STAI-II scores $(p>0.05)$. The parents most commonly had a desire to learn all of the possible complications associated with the surgery and with the anesthesia. There was no significant difference in the STAI scores between the male and female parents $(p>0.05)$. The average STAI I and STAI-II values were $48.0 \pm 7.6$ and $45.3 \pm 7.0$, respectively. In our study, 42 of the parents were university graduates, 42 of them only finished secondary or high school, and 38 only finished primary school; there was a significant difference between these three groups and anxiety $(p<0.05)$ (Table 1$)$. There also was a positive correlation between education and STAI-II $(p=0.001)$. Anxiety was less in the high school and university graduates. There was a negative correlation between wealth and STAI-II $(p=0.01)$ (constant state of anxiety). STAI-II was significantly different within the groups $(p=0.01)$. Those who had steady jobs, who were counseled by the surgeon, and those who had previously undergone anesthesia or surgery had less anxiety than those who did not $(p<0.05)$. There was significant correlation between those parents who had previously received anesthesia and STAI-I $(p=0.08)$. Parents concerns included the possibility of not waking up postoperatively or experiencing pain.
Table 1. Compare of different of STAI parameters and result with statistic values of anxiety and associated factors among parents of children undergoing mild surgery

\begin{tabular}{|c|c|c|c|c|}
\hline Parameters & $\begin{array}{c}\text { STAI I } \\
\text { Mean } \pm \text { SD }\end{array}$ & $\mathrm{p}$ & $\begin{array}{c}\text { STAI II } \\
\text { Mean } \pm \text { SD }\end{array}$ & $\mathrm{p}$ \\
\hline \multicolumn{5}{|l|}{ Gender } \\
\hline Male & $48.4 \pm 7.1$ & *0.406 & $45.0 \pm 6.8$ & ${ }^{*} 0.477$ \\
\hline Female & $47.2 \pm 8.4$ & & $45.9 \pm 7.4$ & \\
\hline \multicolumn{5}{|l|}{ Education } \\
\hline Primary school & $48.3 \pm 7.4$ & & $47.4 \pm 6.4$ & \\
\hline High /secondary school & $47.4 \pm 6.8$ & 0.001 & $46.7 \pm 6.7$ & 0.001 \\
\hline University & $48.2 \pm 8.7$ & & $42.0 \pm 6.9$ & \\
\hline \multicolumn{5}{|l|}{ Employment } \\
\hline No job & $49.9 \pm 7.0$ & $* * * 0126$ & $45.1 \pm 5.8$ & $* * * \cap \cap 01$ \\
\hline Irregular job & $46.3 \pm 8.1$ & $0.1<0$ & $48.5 \pm 6.8$ & 0.001 \\
\hline Regular Job & $48.1 \pm 7.3$ & & $42.7 \pm 6.9$ & \\
\hline \multicolumn{5}{|c|}{$\begin{array}{l}\text { Previously been administered } \\
\text { anesthesia and surgery }\end{array}$} \\
\hline No & $47.2 \pm 7.2$ & *0.008 & $45.3 \pm 6.9$ & ${ }^{\star} 0.967$ \\
\hline Yes & $52.2 \pm 8.2$ & & $45.3 \pm 8.0$ & \\
\hline \multicolumn{5}{|l|}{ Knowledge/Information } \\
\hline Not ask & $49.2 \pm 5.6$ & *0.512 & $50.3 \pm 6.8$ & *0.015 \\
\hline Ask & $47.7 \pm 8.0$ & & $44.6 \pm 6.9$ & \\
\hline \multicolumn{5}{|l|}{ Complication } \\
\hline Want to learn & $47.8 \pm 6.9$ & *0.799 & $46.8 \pm 4.8$ & *0.380 \\
\hline Not want & $48.0 \pm 7.7$ & & $45.1 \pm 7.3$ & \\
\hline \multicolumn{5}{|l|}{ Anesthetic concerns } \\
\hline No & $45.2 \pm 8.4$ & ${ }^{*} 0.026$ & $44.5 \pm 7.0$ & *0.463 \\
\hline Yes & $48.7 \pm 7.1$ & & $45,6 \pm 7.1$ & \\
\hline Wealth & $r=-0.124$ & ${ }^{* *} 0.173$ & $r=-0.257$ & ${ }^{* *} 0.004$ \\
\hline
\end{tabular}

*Independent T test, ** Sperman's rho correlation test, ${ }^{* * *}$ One -way ANOVA test (Tukey HD) 


\section{DISCUSSION}

Our results indicate that a higher level of education, a steady job, counseling from the surgeon, having previously been administered anesthesia, and increased wealth were associated with lesser anxiety among parents of children who were to undergo outpatient surgery.

Outpatient surgeries are rapidly increasing throughout the world. Given the increased quality of services, expectations of patients and their relatives are increasing every day. We measured parent anxiety using the STAI-I and STAI-II questionnaires. Also the types of surgery were selected for homogeneity in our study (only including surgery of the tonsils and adenoids). This homogeneity was important for statistical comparisons to avoid bias.

Our average scores were 47.96 and 45.32 for STAI-1 and STAI-II, respectively. Anxiety regarding the surgery from parents and relatives can cause anxiety in children, which may result in postoperative behavioral disorders. The average score gives information of level of anxiety. There were few studies regarding the analysis of anxiety in the parents of pediatric patients undergoing outpatient surgery in literature recently. Most articles focus on anxiety of the children themselves and were not studied in homogeneous groups. For example Domar et al. [9] as high as 523 samples studied with patients themselves. They found an average score of anxiety was 45 in their study. Despite the various sampling and target groups values of scores are compatible with our results.

Gender usually affects anxiety differently. Although STA-II was increased in the female group, STAI-I and STAI-II was not different with gender significant statistically in our study. The study by Moerman et al. [10] (320 patients) revealed that women have significantly higher anxiety than men. In addition, Badner et al. [11] also found a significant difference in anxiety levels between men and women. Inconsistent with previous literature our different result may be due to decisions of parents to choose surgeons they previously knew and to choose private hospital settings prior to the operation. Meanwhile, Domar et al [9] reported that sex differences may simply reflect voluntariness to admit anxiety as these studies use self-report measures of psychologic states and some time these results can be biased. For example; for women undergoing gynecologic surgery, patients having surgery for a malignancy in this group could deviate the results.
We found that higher education levels was associated with lesser degrees of anxiety $(p<0.05)$. Moerman et al. [10] reported that higher levels of education led to decreased anxiety, while Caumo et al. [12] reported that higher education levels could increase anxiety. Shevde et al. [13] reported that education levels did not affect anxiety. Franck et al [14] reported in their review that education positively affects parents' and children's anxiety. Although there have been conflicting reports on the level of education [11-13] we could say that some of the literature supports our results.

Counseling by the surgeon and being informed about the disease/surgery also decreased parent anxiety $(p<0.05)$. According to our own clinical experience, these aforementioned factors are the most important, as they can reduce anxiety and strengthen the doctor-patient relationship. Meanwhile, the reliability of surgeon or anesthesiologist was important for parents. Currently some articles report that being informed reduced parents' anxiety and they were more satisfied in the preoperative period $[1,4$, 15-17]. Also Augsornwan et al [15] reported that receival of information on disease, medications and self care could decrease parents' anxiety. These results were consistent with that of our study. Also Martin et al [16] reported that reassurance of mothers' and fathers' also decreased children's anxiety.

Age is controversial in anxiety. We found that age did not affect preoperative anxiety which has also been previously reported [9-11]. However, Ramsay et al [18] reported that there were higher anxiety scores for those who were middle-aged, which may be because this age group has more responsibilities. Sheva et al. [13] reported that the elderly had lower preoperative anxiety. We did not find any differences between age and anxiety in our study. Our parent group's average age was $36 \pm 6.8$. This age group is an age of maturity and also the average age of the patients collected in between Thirty to forty years. Probably from these results we did not find any statistically difference between anxiety and age $(p>0.05)$.

Parents who had previously been administered anesthesia or those who had a surgical history had less anxiety $(p<0.05)$. These results are in accordance with those from Thompson's [19] study that parents who had been previously been administered anesthesia were identified 'non-anxious' parents.

To the best of our knowledge we could not identify any study correlating the factor of wealth with 
STAI in parents of operated children. Nevertheless, we found that higher level of wealth and a steady job may also decrease parents' anxiety levels $(p<0.05)$. We think this point is important in societies with low or middle-income economies.

In conclusion, our results indicate that a higher level of education, having a steady job, being counseled by the surgeon or anesthesiologist, having a higher level of wealth could decrease preoperative anxiety. The future planning may have to identify affecting other factors on anxiety and thus, we would like to develop more comfortable and healthy alternative therapies for patients.

\section{Acknowledgments}

The authors thank Yilmaz Palanci, assisstant professor, from the Department of Public Health, Dicle University School of Medicine, for his valuable statistical assistance and Zeynep Meltem Akkurt from the Department of Dermatology for her valuable support and DUBAP for their editing system.

\section{REFERENCES}

1. Markland $D$ and Lew $H$. Anxiety relaxation and anaesthesia for day- case surgery. Br J Clin Psychol 1993;32:493-504.

2. Yager J, Giltlin M. "Clinical manifestations of psychiatric disorders”, Kaplan, HI\& Sadock, BJ (Eds.), Comprehensive textbook of psychiatry 1995;637-639.

3. Spielberger CD, Gorsuch RL, Lushene R, et al. Manual for the State-Trait Anxiety Inventory. Palo Alto, CA:Consulting psychologists Press, Inc. 1983.

4. Thompson, ML. Information-seeking coping and anxiety in school-age children anticipating surgery. Child Health Care 1994;23:87-97.

5. Wollin SR, Plummer JL, Owen $\mathrm{H}$, et al. Anxiety in children having elective surgery. J Pediatr Nurs 2004;19:128-132.

6. Kain ZN, Caldwell AA, and Wang SM. Psychological preparation of the parent and pediatric surgical patient. Anesthesiol Clin North Am 2002;20:29-44.
7. Spielberger, CD. Manual for the State-Trait Anxiety Inventory for Children, Consulting Psychologists Press, Palo Alto, Calif, USA, 1973.

8. Haugen AS, Eide GE, Olsen MV, et al. Anxiety in the operating theatre: a study of frequency and environmental impact in patients having local, plexus or regional anaesthesia. J Clin Nurs 2009;18:2301-2310.

9. Domar AD, Everett LL, and Keller MG. Preoperative anxiety: Is it a predictable entity?. Anesth Analg 1989;69:763-767.

10. Moerman N, Van Dam FS, Muller MJ, and Oosting $\mathrm{H}$. The Amsterdam preoperative anxiety and information scale (APAIS). Anesth Analg 1996;82:445-451.

11. Badner $\mathrm{NH}$, Nielson WR, Munk $\mathrm{S}$, et al. Preoperative anxiety: Detection and contributing factors. Can J Anaesth 1990;37:444-447.

12. Caumo W, Schmidt AP, Schneider CN, et al. Risk factors for preoperative anxiety in adults. Acta Anaesthesiol Scand 2001;45:298-307.

13. Shevde K, and Panagopoulos G. A survey of 800 patients' knowledge, attitudes, and concerns regarding anesthesia. Anesth Analg 1991;73:190-198.

14. Franck LS, Spencer C. Informing parents about anaesthesia for children's surgery: a critical literature review. Patient Educ Couns 2005;59:117-125.

15. Augsornwan D, Pattangtanang P, Pikhunthod K, Surakunprapha P. Nursing outcome in patients with craniofacial anomalies who underwent operation. J Med Assoc Thai 2012;95:11:62-66.

16. Martin SR, Chorney JM, Cohen LL, and Kain ZN. Sequential Analysis of Mothers'and Fathers'Reassurance and Children's Postoperative Distress. Journal of Pediatric Psychology 2013;38:1121-1129

17. Bray L, Callery P and Kirk S. A qualitative study of the pre-operative preparation of children, young people and their parents' for planned continence surgery: experiences and expectations. Journal of Clinical Nursing 2012;21:1964-1973.

18. Ramsay, MA. A survey of pre-operative fear. Anaesthesia 1972;27:396-402.

19. Thompson N, Irwin MG, Gunawardene WM, and Chan L. Pre-operative parental anxiety. Anaesthesia 1996;51:1008-1012. 